\title{
Discriminant milk components of Bactrian camel (Camelus bactrianus), dromedary (Camelus dromedarius) and hybrids
}

\author{
Bernard FAYE $^{1 *}$, Gaukhar KonUSPAYEVA ${ }^{1,2}$, Samir MESSAD $^{1}$, Gérard LoISEAU $^{1}$ \\ ${ }^{1}$ Centre de Coopération Internationale en Recherche Agronomique pour le Développement (CIRAD), \\ Campus international de Baillarguet TA C/dir B, 34398 Montpellier Cedex, France \\ ${ }^{2}$ Kazakh State University Al Farabi, 71 av. Al-Farabi, 050013 Almaty, Kazakhstan
}

Received 21 December 2007 - Accepted 5 March 2008

\begin{abstract}
In Kazakhstan, the cohabitation of Bactrian camels, dromedaries and their hybrids is a common feature even within farms. The physico-chemical composition of 147 milk samples from 57 Bactrians, 70 dromedaries and 20 hybrids was determined. The samples came from 4 different regions and were collected at 4 different seasons within a year. Compared with dromedary, Bactrian camel milk had significantly higher fat (6.67 vs. 5.94\%), vitamin C (177 vs. $\left.152 \mathrm{mg} \cdot \mathrm{L}^{-1}\right)$, calcium (1.30 vs. $\left.1.16 \mathrm{~g} \cdot \mathrm{L}^{-1}\right)$ and phosphorus $\left(1.07 \mathrm{vs.} 0.91 \mathrm{~g} \cdot \mathrm{L}^{-1}\right)$. The iodine index value was significantly higher in dromedary (16.69) than in Bactrian milk (14.99). To distinguish Bactrian milk from dromedary milk, a discriminant analysis was carried out after discarding seasonal and regional variability. The discriminant parameters were phosphorus (linear discriminant coefficient $=-1.00), \mathrm{pH}(-0.408)$, vitamin $\mathrm{C}(-0.377)$ and fat content $(-0.226)$, in higher concentrations in Bactrian than in dromedary milk. The iodine index $(0.287)$ was higher in dromedary milk. After quadratic discriminant analysis, milk composition can predict species, with $75.4 \%$ well-classed. The milk composition of the hybrids was intermediary but with a low discriminant power.
\end{abstract}

dromedary milk / hybrid / Bactrian / discriminant analysis

摘要 - 双峰骆驼 (Camelus bactrianus) 、单峰骆驼 (Camelus dromedarius) 和杂交骆驼乳成 分的区别。在哈萨克斯坦, 单峰骆驼、双峰骆驼和他们的杂交种混合饲养是非常普遍的现 象。本研究共测定了 147 个乳样品 (57 头双峰骆驼、70头单峰骆驼和 20 头杂交骆驼) 的 物理化学组成。这些样品是从 4 个不同地区、一年内的 4 个不同季节采集的样品。双峰 骆驼与单峰骆驼比较, 前者乳中的脂肪 (6.67 对 5.94\%)、维生素 C (177 对 $152 \mathrm{mg} \cdot \mathrm{L}^{-1}$ )、钙 (1.30 对 $\left.1.16 \mathrm{~g} \cdot \mathrm{L}^{-1}\right)$ 和 (1.07 对 $\left.0.91 \mathrm{~g} \cdot \mathrm{L}^{-1}\right)$ 显著高于后者, 但单峰骆驼奶的碘值 (16.69) 显著 高于双峰骆驼 (14.99)。在排除了地区和季节的差异后, 采用鉴别分析技术区别双峰和单峰 骆驼乳的组成。在双峰骆驼乳比单峰骆驼乳浓度高时, 设定的鉴别参数分别是磷 (线性鉴 别系数 $=-1.00) 、 \mathrm{pH}(-0.408)$ 、维生素 C $(-0.377)$ 和脂肪含量 $(-0.226)$ 。单峰骆驼奶的碘值 (0.287) 较高。根据建立的鉴别分析二次方程, 可以根据奶的组成来鉴定骆驼的种类, 该方程 的准确率为 $75.4 \%$ 。杂交种骆驼乳的组成介于两者之间, 但是其识别率较低。

单峰骆驼乳 / 双峰骆驼 / 杂交种骆驼 / 鉴别分析

* Corresponding author (通讯作者): faye@cirad.fr 
Résumé - Paramètres discriminant le lait de chameau de Bactriane (Camelus bactrianus) du lait de dromadaire (Camelus dromedarius). Au Kazakhstan, la cohabitation du chameau de Bactriane, du dromadaire et de leurs hybrides est un fait courant au sein même des fermes. La composition physico-chimique de 147 échantillons de lait provenant de 57 chameaux de Bactriane, 70 dromadaires et 20 hybrides a été déterminée. Les échantillons ont été prélevés dans 4 fermes provenant de 4 régions différentes aux 4 saisons au cours d'une année. Comparé à celui de dromadaire, le lait de chamelle de Bactriane apparaît plus riche en matière grasse (6,67 vs. 5,94 \%), vitamine $\mathrm{C}\left(177\right.$ vs. $\left.152 \mathrm{mg} \cdot \mathrm{L}^{-1}\right)$, calcium $\left(1,30\right.$ vs. $\left.1,16 \mathrm{~g} \cdot \mathrm{L}^{-1}\right)$, et phosphore $\left(1,07 \mathrm{vs.} 0,91 \mathrm{~g} \cdot \mathrm{L}^{-1}\right)$. L'indice d'iode est significativement plus élevé dans le lait de dromadaire $(16,69)$ que dans le lait de chamelle de Bactriane $(14,99)$. Afin de distinguer les deux types de lait, une analyse discriminante a été mise en œuvre après avoir éliminé les effets liés à la variabilité saisonnière et régionale. Les paramètres discriminants sont le phosphore (coefficient linéaire discriminant $=-1,00$ ), le $\mathrm{pH}$ $(-0,408)$, la vitamine $\mathrm{C}(-0,377)$ et la matière grasse $(-0,226)$, en concentrations plus élevées dans le lait de Bactriane que dans celui de dromadaire. L'indice d'iode $(0,287)$ était plus élevé dans le lait de dromadaire. Après une analyse discriminante quadratique, on peut prédire d'après la composition du lait, l'origine spécifique avec un pourcentage de bien classés de 75,4 \%. La composition chimique du lait des hybrides s'est avérée intermédiaire mais avec un faible pouvoir discriminant.

lait de dromadaire / hybride / Bactriane / analyse discriminante

\section{INTRODUCTION}

The camel population in Kazakhstan includes the double-humped camel (Camelus bactrianus), the one-humped camel (Camelus dromedarius) and a wide range of hybrids at different levels of hybridization [29]. There is relatively little data on camel milk composition [12, 25] compared with other dairy species. In a recent meta-analysis [19], the international bibliographical database consultation revealed only 82 references between 1905 [5] and 2006 [11]. In most cases, very few milk samples were analyzed, and the origin of the sampled animals was not systematically described. The differences between breeds, stage of lactation, season and type of diet were rarely mentioned. And in general, the sampling and analytical procedures were roughly described. The available comparisons between Bactrian and dromedary milk samples issue from reviews in the literature. To our knowledge, no field comparison taking into account common breeding and farming conditions has been published. In Kazakhstan, both species often cohabit in the same environmental conditions or sometimes in the same farm [22]. It was thus possible to study species difference in milk composition and to determine the milk components differentiating one species from the other by discriminant analysis. The aim of this paper was to identify the physico-chemical milk parameters that discriminated these two close species by eliminating other known variation factors such as regional or seasonal variability. In addition, the hybrids' milk was compared. The results may contribute to establishing specific milk standards.

\section{MATERIALS AND METHODS}

\subsection{Sampling procedure}

To obtain maximum variability, the camel milk was sampled in 4 different regions at extreme points of Kazakhstan: Almaty, Atyrau, Aralsk and Shymkent (the maximum distance between the various points was over $3500 \mathrm{~km}$ ) and during the 4 seasons of the year. In total, 147 samples from different animals were used to determine the raw camel milk gross composition (Tab. I). The samples were randomly collected among Bactrian ( $n=$ 57), dromedary $(n=70)$ and hybrid 
Table I. Raw camel milk sampling design by species $\times$ season $\times$ region.

\begin{tabular}{|c|c|c|c|c|c|c|}
\hline & & \multicolumn{4}{|c|}{ Region } & \multirow[b]{2}{*}{ Total } \\
\hline & & Almaty & Atyraou & Aralsk & Chymkent & \\
\hline \multirow{4}{*}{ Bactrian } & Winter & 4 & 7 & 2 & 0 & 13 \\
\hline & Spring & 5 & 5 & 5 & 3 & 18 \\
\hline & Summer & 4 & 7 & 1 & 2 & 14 \\
\hline & Fall & 4 & 6 & 1 & 1 & 12 \\
\hline \multicolumn{2}{|c|}{ Total Bactrian } & 17 & 25 & 9 & 6 & 57 \\
\hline \multirow{4}{*}{ Dromedary } & Winter & 5 & 2 & 2 & 2 & 11 \\
\hline & Spring & 14 & 2 & 2 & 4 & 22 \\
\hline & Summer & 20 & 1 & 1 & 6 & 28 \\
\hline & Fall & 2 & 1 & 0 & 6 & 9 \\
\hline \multicolumn{2}{|c|}{ Total dromedary } & 41 & 6 & 5 & 18 & 70 \\
\hline \multirow{4}{*}{ Hybrid } & Winter & 0 & 0 & 0 & 2 & 2 \\
\hline & Spring & 0 & 1 & 4 & 5 & 10 \\
\hline & Summer & 0 & 0 & 2 & 5 & 7 \\
\hline & Fall & 0 & 0 & 0 & 1 & 1 \\
\hline \multicolumn{2}{|c|}{ Total hybrid } & 0 & 1 & 6 & 13 & 20 \\
\hline \multicolumn{2}{|c|}{ Total } & 58 & 32 & 20 & 37 & 147 \\
\hline
\end{tabular}

( $n=20)$ lactating she-camels at the milking time in one private farm per region. In Kazakhstan, the calving season is short and occurs within less than two months. Bactrian camel milk samples originated from different Kazakh types, depending on their geographical location: Uralobokeliki, Kyzylorda and Ontustik-Kazakhstan [20, 29]. Milk samples from dromedary camels came from the Turkmen Arvana breed [7, 28]. Hybrid samples involved F1 or F2 crossbred animals. The F1 crossbred Bactrian male and dromedary female is called Iner (M) or Iner-maya (F). The F1 crossbred dromedary male and Bactrian female is called Nar (M) and Nar-maya $(\mathrm{F})$. The F2 crossbred Iner $\times$ Bactrian is called Kospak and the F2 crossbred Nar $\times$ dromedary, Kurt. In all cases, milk was obtained by manual milking and kept frozen at $-20{ }^{\circ} \mathrm{C}$ until analysis, except for vitamin $\mathrm{C}$, determined on fresh milk.

\subsection{Laboratory analysis}

The physico-chemical parameters involved in differentiating the two species' milk were classical components: total protein (TP), fat matter (FM), iodine index (II, that expressed the unsaturated part of fat matter), lactose (La), calcium (Ca), phosphorus $(\mathrm{P})$, iron $(\mathrm{Fe})$ and vitamin $\mathrm{C}$ (VitC). Some physical parameters were included: Dornic acidity (Do), pH, density (De), and finally, skimmed dry matter (SDM).

Nitrogen (N) was determined by the Kjeldahl method (Ref: ISO5983) and the conversion $\mathrm{N} \times 6.38$ was used to quantify the total protein. The density, skimmed dry matter and fat matter were quantified using mid-infrared spectrophotometry equipment (Lactan-4). The iodine index was measured by the Margoshes method [3]. The iodine index expressed the mass of 
diiodine $\left(\mathrm{I}_{2}\right)$ in a gram fixed by addition on $100 \mathrm{~g}$ of lipids.

The lactose was determined by Bertrand's method (reference NF V 04213, 1971) and by using an enzymatic kit (kit UV-method, Enzymatic BioAnalysis/Food Analysis, Cat. No 10176303 035, Boehringer Mannheim). Minerals $(\mathrm{Ca}, \mathrm{P}$ and $\mathrm{Fe})$ were determined with a plasma emission spectrometer ICP Varian-Vista after dry way mineralization and discarding silica with fluorhydric acid. Vitamin C was quantified by the colorimetric method using 2.6 di-chlorindophenol (2.6-DIPh) [8]. Dornic acidity was determined by Dornic sodium hydroxide after mixing milk samples with phenolphtalein solution. A classical $\mathrm{pH}$-meter was used for determination of $\mathrm{pH}$.

\subsection{Statistical procedure}

Discriminant analysis was the retained method to determine the parameters explaining the differences in the physicochemical composition of dromedary and Bactrian camel milk. Because of the significant number of parameters describing the chemical composition of milk samples, their various geographical and seasonal origins, and a secondary aim concerning the comparison with hybrids, the statistical procedure followed 3 steps.

\section{Step 1}

The physico-chemical parameters (TP, FM, II, La, Ca, P, Fe, VitC, Do, pH, De and SDM), candidates for discrimination by the factor "species", were selected after the results of the adjustment of each parameter by a simple linear model according to the factors "species", "region" and "season" and the interactions of order one. To assume assumptions of multivariate normality distribution and homoscedasticity, parameters with skewed distribution were log-transformed. In order to include total protein in the model (which is an important part of milk composition), the retained significant level was 0.15 . When two parameters were correlated (Pearson correlation), only one was retained for further analysis. For example, as $\mathrm{Ca}$ and $\mathrm{P}$ were correlated, only $\mathrm{P}$ was retained. So, only independent variables were finally retained in the discriminant model.

\section{Step 2}

The main constraint was that the milk samples were collected in very contrasted seasons and regions, inducing an independent variability to species. So, the description by species was conditioned to these two factors. To discard these effects, a data table including 127 milk samples from Bactrian camels and dromedaries described by a set of parameters linked to species effects was prepared. The elimination of regional and seasonal effects was achieved with a similar method described in detail by Doledec and Chessel [9]. The procedure is summarized below.

Let $X$ be the matrix of $p$ biochemical parameters describing $n$ samples of milk. $x_{i k l}^{j}$ was the $i^{\text {th }}(i=1, \ldots, n)$ observation of the $j^{\text {th }}(j=1, \ldots, p)$ parameter for the $k^{\text {th }}$ region and the $l^{\text {th }}$ season.

$X$ was preliminarily normalized. Then a new matrix called $Z$ was obtained with the general term given by:

$$
z_{i k l}^{j}=\frac{x_{i k l}^{j}-\bar{x}^{j}}{\sigma_{x}^{j}}
$$

with $\bar{x}^{j}$ and $\sigma_{x}^{j}$, respectively, the mean and the standard deviation of parameter $j$.

As the additive effects of the region and the season were not taken into account, the general term of the biochemical parameters table analyzed by discriminant analysis was written as:

$$
\dot{z}_{i}^{j}=z_{i k l}^{j}-\bar{z}_{k}^{j}-\bar{z}_{l}^{j}
$$

with $\bar{z}_{k}^{j}$ the mean of parameter $j$ in the region $k$ and $\bar{z}_{l}^{j}$ the mean of parameter $j$ in the season $l$. 
Table II. Coefficients of linear discriminant (LD1) between Bactrian and dromedary camel milk issued from simple discriminant analysis.

\begin{tabular}{lr}
\hline Parameters & \multicolumn{1}{c}{ LD1 } \\
\hline Phosphorus & -1.00076 \\
pH & -0.40802 \\
Vitamin C & -0.37738 \\
Iodine index & 0.28723 \\
Fat matter & -0.22694 \\
Total protein & -0.00089 \\
\hline
\end{tabular}

\section{Step 3}

As the within-species covariance matrices were not equal, a quadratic discriminant analysis was performed [30]. A discriminant function was obtained. This function was a combination of the physico-chemical parameters calculated so as to catch the maximum of proportion of between-species variance. The discriminant function was represented by the linear form:

$$
F=w_{(1)} \dot{z}^{1}+w_{(2)} \dot{z}^{2}+\ldots+w_{(p)} \dot{z}^{p}
$$

with $\dot{z}^{j}$ the $j^{\text {th }}$ transformed physicochemical parameter and $w_{(j)}$ the $j^{\text {th }}$ discriminant coefficient (or canonical weight).

The function discriminated by plotting the distribution [26] of individual (milk sample) scores according to each group could be visualized (Fig. 1). In addition, the discriminant function coefficients (Tab. II) help to evaluate each variable's contribution.

The classification function was validated by the estimation of the well-classed rate obtained by cross-validation. The predicted group for each sample's milk was achieved with the estimation of posterior probabilities.

The method of leave-one-out crossvalidation was used: one sample was discarded as the validation data and the remaining observations as the training data. This was repeated such that each observation in the sample was used once as the validation data.
Statistical analyses were achieved with the MASS package [30] used with the R statistical software [4].

\section{RESULTS}

\subsection{Mean composition of camel milk according to species}

The Bactrian milk had significantly higher fat, vitamin $\mathrm{C}$, calcium and phosphorus contents than the dromedary milk (Tab. III). Dromedary milk had less Dornic acidity than other species. Hybrid camel milk had a significantly higher iodine index and density than other species. No significant differences were reported for skimmed dry matter, lactose or iron. The differences in total protein content were not significant at the $0.05 P$ level.

\subsection{Selection of independent variables for discriminating analysis}

Six non-correlated parameters were selected as convenient variables to discriminate the species: total proteins, fat, iodine index, vitamin $\mathrm{C}, \mathrm{pH}$ and phosphorus (Fig. 2). Dornic acidity was highly correlated to $\mathrm{pH}$, and density to the fat and total protein. They were therefore discarded from the subsequent model. Calcium and phosphorus were significantly correlated $(P<0.001)$. Calcium was therefore also discarded from the subsequent model because the $P$ value for phosphorus was much higher.

\subsection{Predictive discriminant analysis Bactrian-dromedary}

The most discriminant parameter was the phosphorus concentration according to the coefficient of linear discriminants 


\section{Discriminant limit}

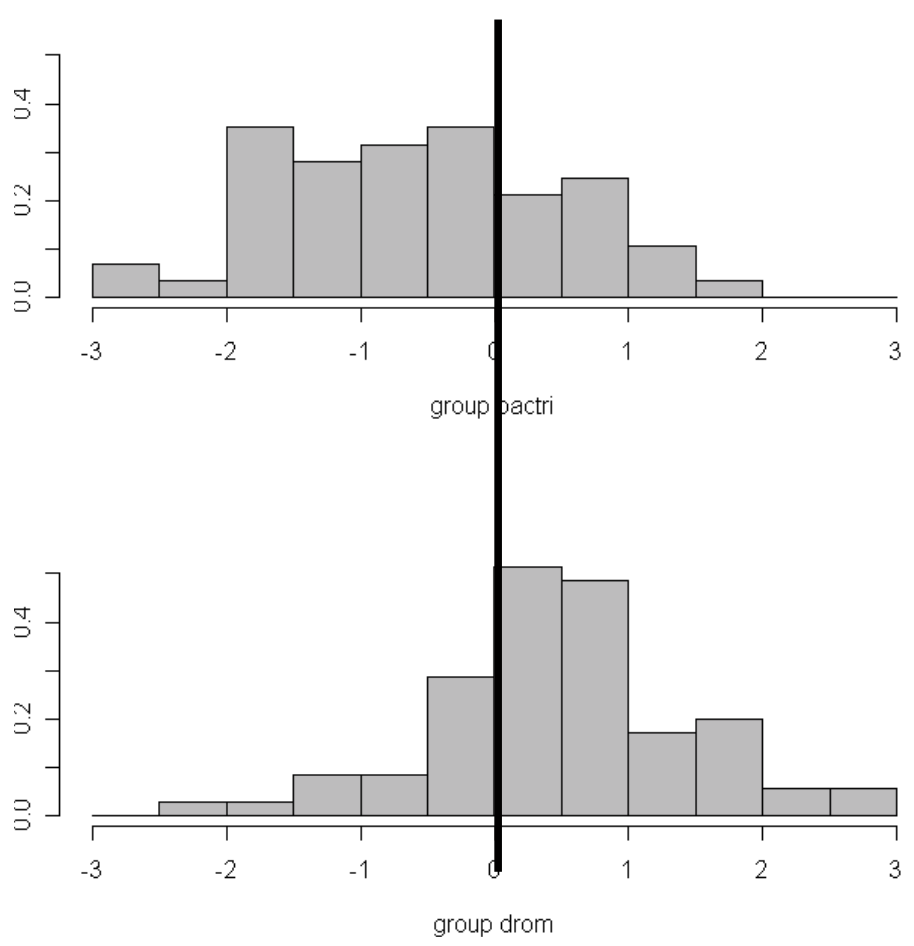

Figure 1. Distribution of the discriminant scores of Bactrian (group bactri) and dromedary milk samples (group drom) around the discriminant limit (black line).

Table III. Mean \pm standard error of principal components in raw camel milk in Kazakhstan according to the species $(n=147)$ and probability level from ANOVA. Only significant levels at $P<0.15$ for species effects are reported in bold.

\begin{tabular}{lcccc}
\hline Parameters & Bactrian & Dromedary & Hybrid & $P$ value \\
\hline FM $(\%)$ & $6.67 \pm 2.93$ & $5.94 \pm 2.26$ & $6.09 \pm 1.81$ & $\mathbf{0 . 0 4}$ \\
$\mathrm{SDM}(\%)$ & $10.64 \pm 3.11$ & $10.87 \pm 3.19$ & $11.01 \pm 2.66$ & 0.24 \\
$\mathrm{De}\left({ }^{\circ} \mathrm{A}\right)$ & $33.02 \pm 6.77$ & $34.66 \pm 5.85$ & $37.04 \pm 8.54$ & $<\mathbf{0 . 0 0 1}$ \\
$\mathrm{pH}$ & $6.55 \pm 0.40$ & $6.46 \pm 0.51$ & $6.36 \pm 0.56$ & 0.05 \\
$\mathrm{Do}\left({ }^{\circ} \mathrm{D}\right)$ & $27.47 \pm 12.48$ & $24.04 \pm 13.92$ & $27.27 \pm 11.47$ & $<\mathbf{0 . 0 0 1}$ \\
$\mathrm{La}(\%)$ & $2.77 \pm 0.96$ & $3.12 \pm 0.92$ & $3.04 \pm 0.60$ & 0.45 \\
$\mathrm{Vit} \mathrm{C}\left(\mathrm{mg} \cdot \mathrm{L}^{-1}\right)$ & $177 \pm 109$ & $152 \pm 91$ & $133 \pm 133$ & $<\mathbf{0 . 0 0 1}$ \\
$\mathrm{II}$ & $14.99 \pm 6.94$ & $16.62 \pm 9.40$ & $22.29 \pm 8.53$ & $\mathbf{0 . 0 2}$ \\
$\mathrm{TP}(\%)$ & $5.23 \pm 1.17$ & $4.76 \pm 1.13$ & $5.15 \pm 1.59$ & $\mathbf{0 . 1 1}$ \\
$\mathrm{Ca}\left(\mathrm{g} \cdot \mathrm{L}^{-1}\right)$ & $1.303 \pm 0.287$ & $1.163 \pm 0.273$ & $1.257 \pm 0.268$ & $\mathbf{0 . 0 0 3}$ \\
$\mathrm{P}\left(\mathrm{g} \cdot \mathrm{L}^{-1}\right)$ & $1.075 \pm 0.177$ & $0.915 \pm 0.190$ & $1.067 \pm 0.273$ & $<\mathbf{0 . 0 0 1}$ \\
Fe $\left(\mathrm{mg} \cdot \mathrm{L}^{-1}\right)$ & $2.11 \pm 1.63$ & $1.93 \pm 1.06$ & $2.01 \pm 0.78$ & 0.55 \\
\hline
\end{tabular}




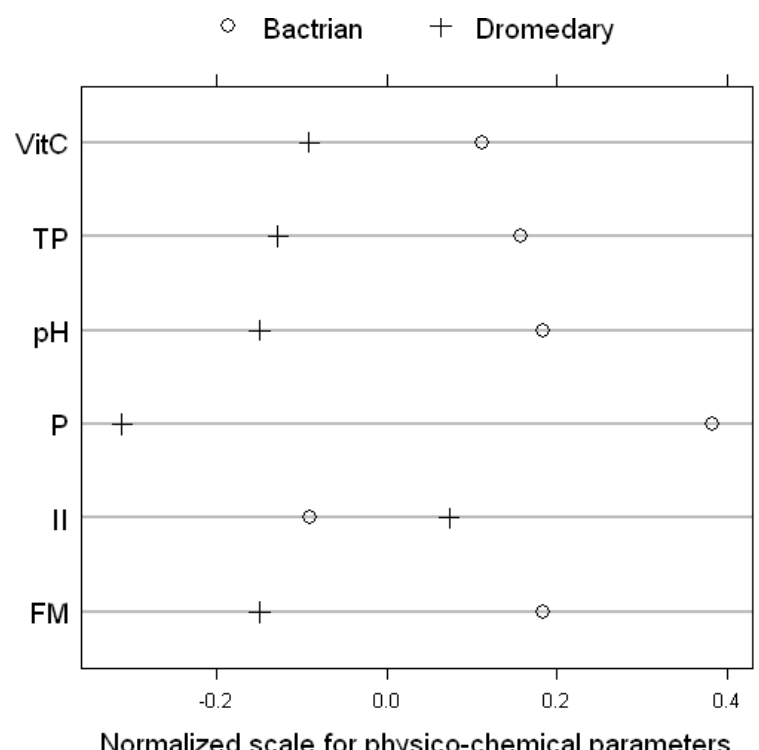

Figure 2. Normalized scale for the physico-chemical parameters (VitC, TP, pH, P, II and FM) of Bactrian (o) and dromedary (+) milk samples participating in the discriminant function.

(LD1) reported in Table II. Phosphorus was followed by a group of parameters including $\mathrm{pH}$, vitamin $\mathrm{C}$, iodine index and fat. Total protein was not very discriminant. The Bactrian milk samples had higher phosphorus contents regardless of the season or region. The other main discriminant parameters in Bactrian milk were, successively, $\mathrm{pH}$, vitamin $\mathrm{C}$, fat and total protein. The iodine index was only higher in dromedary milk (Tab. III).

After cross-validation (leave-one-out cross-validation), the percentage of wellclassed samples was $75.4 \%$. As the Bactrian population seemed more heterogeneous than the dromedary's, the prediction was less powerful for Bactrian (73.6\%) than for dromedary (78.5\%) (Fig. 1).

\subsection{Discriminant analysis including hybrids}

The same non-correlated parameters were selected as variables to discriminate the 3 species: total proteins, fat matter, iodine index, vitamin $\mathrm{C}, \mathrm{pH}$ and phosphorus. The homogeneity of variance in the hybrid population as well as the low similarity of co-variance allowed us to achieve a descriptive discriminant analysis only. In some cases, the hybrids' values were between those of Bactrian and dromedary (FM, pH), close to those of dromedary (vitC) or of Bactrian (P) or out (II and TP) (Fig. 3). The hybrid group was multimodal. Half of the hybrids' samples were closely related to the dromedary and $40 \%$ to the Bactrian.

\section{DISCUSSION}

The discriminant analysis allowed us to take into account all the parameters simultaneously. The correlated parameters being discarded and the region and season effects being deleted, the between-species discrimination could be considered convenient. The physiological status was not 


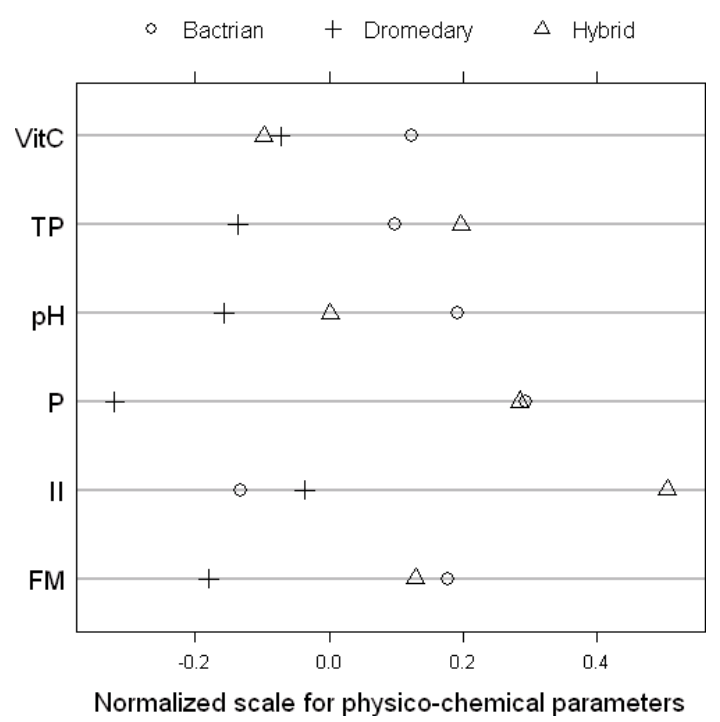

Figure 3. Normalized scale for the physico-chemical parameters (VitC, TP, pH, P, II and FM) of Bactrian (o), dromedary $(+)$ and hybrid $(\Delta)$ milk samples participating in the discriminant function.

retained as an important variation factor because the calving period occurred within less than two months (February-March). So, the season factor included the physiological status of the sampled animals. The farm was not taken into account in the model because the feeding practices and the ecology of the pasture were linked to the region. We assumed that the region factor included the farm variability. Elsewhere, the two species were not present in all the farms and the number of milk samples per farm was sometimes low for a given season.

\subsection{Camel milk composition}

On average, Bactrian milk was considered to have a higher fat content $[18,29]$. References from central Asia where Bactrian camels live (Kazakhstan, Mongolia, China and Russia) reported high milk fat contents in these camels' milk compared with those found in the dromedaries', regardless of their origin (Africa or SouthAsia). Two references mentioned a com- parison between Bactrian and dromedary species: 5.5 vs. $4.15 \mathrm{~g} \cdot \mathrm{L}^{-1}$ in China [31], 5.45 vs. $4.47 \mathrm{~g} \cdot \mathrm{L}^{-1}$ in Mongolia [17]. In our results, milk fat values appeared very high compared with the calculated mean from the literature, both for camelids from Central Asia (mainly Bactrian but probably not exclusively: 4.94) and dromedary camel (3.82). However, in spite of the higher fat content in Bactrian milk, this parameter contributed only a small part to the discrimination between the two species.

The difference in protein contents between the two species did not appear remarkable. For example, Zhao [31] reported $3.87 \mathrm{~g} \cdot \mathrm{L}^{-1}$ for Bactrian and $3.45 \mathrm{~g} \cdot \mathrm{L}^{-1}$ for dromedary and Indra and Erdenebaatar [16] 4.43 and $3.53 \mathrm{~g} \cdot \mathrm{L}^{-1}$, respectively. On average, the protein content calculated in 82 references [21] was 3.23 in dromedary and $4.02 \mathrm{~g} \cdot \mathrm{L}^{-1}$ in Central Asia and was lower than our findings. The discriminating power of this parameter was very low. 
No difference in lactose was reported in the two comparative references mentioned above: 4.34 and $4.76 \mathrm{~g} \cdot \mathrm{L}^{-1}$ (Bactrian), and 4.55 and $4.95 \mathrm{~g} \cdot \mathrm{L}^{-1}$ (dromedary) in Zhao [31] and Indra and Erdenebaatar [16], respectively. According to the literature, the lactose mean content was 4.40 in dromedary and $4.73 \mathrm{~g} \cdot \mathrm{L}^{-1}$ in references from Central Asia. These values were higher than our observations. In any case, the lactose content did not allow us to distinguish Bactrian milk from dromedary milk.

On average, mineral matter was in higher quantity in dromedary milk $\left(0.99 \mathrm{~g} \cdot \mathrm{L}^{-1}\right)$ than in references from Central Asia $\left(0.79 \mathrm{~g} \cdot \mathrm{L}^{-1}\right)$ but few data are available on specific minerals.

Phosphorus (and correlatively calcium) was the main discriminant parameter. If the calcium content in our milk samples was close to the literature's data $[2,6,14]$ with values between 1.15 and $1.57 \mathrm{~g} \cdot \mathrm{L}^{-1}$, the phosphorus content in camel milk from Kazakhstan appeared in higher concentration than those of the literature: between $0.63 \mathrm{~g} \cdot \mathrm{L}^{-1}$ [27] and $1.04 \mathrm{~g} \cdot \mathrm{L}^{-1}$ [14]. The higher phosphorus concentration in Bactrian milk compared with dromedary milk could be linked to its higher fat content, especially in phospholipids. Unfortunately, the quantity of phospholipids was not determined in our study. The mineral and organic phosphate linked to caseins could also play a role in explaining the difference, but further analysis is necessary to determine this aspect.

Milk iron content did not discriminate the two camel species. Part of iron is linked to lactoferrin. In a previous publication, no significant difference between species was reported for the lactoferrin content in the milk [16]. The observed iron values in our samples (around $2 \mathrm{mg} \cdot \mathrm{L}^{-1}$ ) were slightly lower (3.0 to $3.4 \mathrm{mg} \cdot \mathrm{L}^{-1}$ ) than those reported by several authors $[1,6,27]$. In some references, very high iron concentrations were reported: $280 \mathrm{mg} \cdot \mathrm{L}^{-1}$ [10].
The lack of standardized methods could explain such differences. Unfortunately, in most of the cases, the analytical method was not clearly described.

The high level of vitamin $\mathrm{C}$ in camel milk is well known [13]. It plays a major part in camel milk's medicinal reputation [19]. According to Farah [12], the reported range was $25-60 \mathrm{mg} \cdot \mathrm{L}^{-1}$, which was lower than our results in both species. Ascorbic acid concentration differed significantly between Sudanese camel breeds [23]. Ascorbic acid is highly unstable (especially with temperature change). In our study, vitamin $\mathrm{C}$ was determined in fresh milk, contrarily to the other authors [13,23] who had analyzed frozen milk. So, the observed differences in milk vitamin $\mathrm{C}$ concentration could be partly explained by the analytical conditions, and probably also by the methods used.

The iodine index was the only discriminant parameter in higher concentration in the dromedary camel. This index was related to the fat composition, notably to the quantity of unsaturated links in fatty acids. In a previous publication based on the same sampling material, it was reported that the proportion of polyunsaturated fatty acids was in higher percentage in dromedary milk [24].

The acidity of camel milk was also a discriminant parameter. The storage and transport conditions of the milk samples were identical for the two species, notably because their cohabitation in the same areas was common. So, the difference in acidity could most probably be attributed to the intrinsic property of the milk. Partly, this difference could be attributed to the vitamin $\mathrm{C}$ (ascorbic acid) [11], in higher concentration in Bactrian milk.

\section{Zootechnical aspect}

On average, milk production is higher in dromedary than in Bactrian camel [15], especially in the Arvana breed, well-known 
for its high dairy potential [7]. So, the lower concentrations of components in dromedary milk could be attributed to a "dilution effect". However, the milk composition in the dromedary from Kazakhstan appeared more closely related to that of Bactrian milk than to that of other dromedaries in the world. There are probably specific environmental conditions (notably feeding) explaining the particular richness of camel milk in this country.

Bactrian and dromedary camels are genetically closely related, but also different species [20]. The observed differences in their milk composition were generally attributed to environmental conditions: Bactrian camels, being more adapted to very cold winters, have fattier milk. However, as the two species sampled in the present study were living under the same conditions, the observed differences could not be attributed to environmental conditions only. In fact, their milk composition was slightly different regardless of the origin of their region (which reflected the feeding variability) or of the seasonal effect (which reflected the physiological stage).

The positioning of the "hybrid" group and its low well-classed percentage could be linked to the high heterogeneousness of this group. In our study, the hybridizing level was not known. The hybrids included F1 (Iner or Nar) as well as F2 (Kospak or Kurt) and F3 animals. The crossbreeding of $\mathrm{F} 1$ animals being achieved with pure breeds (dromedary or Bactrian), it was not surprising to find a high proportion of F2 hybrids closely related to one or the other species.

\section{CONCLUSION}

In similar environments and farming conditions, Bactrian and dromedary camels' milk had a slight difference in their gross composition. The most discriminating parameters concerned chemical (main minerals, vitamin $\mathrm{C}$, fat matter and iodine index) and physical (acidity) aspects. These results confirm that the establishment of standards for camel milk must take into account the different species.

Acknowledgements: The study was supported by the French Ministry of Foreign Affairs (ECONET Programme) and by the French Embassy in Almaty (Kazakhstan). We also thank the camel farmers in Kazakhstan for their exceptional hospitality.

\section{REFERENCES}

[1] Abdelrahim A.G., The chemical composition and nutritional value of camel (Camelus dromedarius) and goat (Capra hircus) milk, World Rev. Anim. Prod. 18 (1987) 9-12.

[2] Abu-Lehia I.H., Composition of camel milk, Milchwissenschaft 42 (1987) 368-371.

[3] Anonymous, Analytical methods of milk composition. Technic-scientific information department (in Russian), Dubrovicy, Soviet Union, 1969.

[4] Anonymous, Development Core Team R: A Language and Environment for Statistical Computing, R Foundation for Statistical Computing, Vienna, Austria, 2007.

[5] Barthe L., La composition du lait de chamelle, J. Pharm. Chim. 21 (1905) 386388.

[6] Bengoumi M., Faye B., Tressol J.C., Composition minérale du lait de chamelle du sud marocain, in: Bonnet P. (Ed.), Actes de 1'atelier Chameaux et dromadaires, animaux laitiers, Nouakchott, Mauritanie, Oct. 24-26, 1994, CIRAD, Montpellier, France, 1998, pp. 145-149.

[7] Cherzekov A., Saparov G., The milk productivity of the camel Arvana breed and its use, in: Faye B., Esenov P. (Eds.), Proceedings of International Workshop Desertification combat and food safety, the added value of camel producers, Ashkhabad, Turkmenistan, April 19-22, 2004, Vol. 362 NATO Sciences Series, Life and Behavioural Sciences, IOS Press Publisher, Amsterdam, The Netherlands, 2005, pp. 215-220.

[8] Dabrowski K., Hinterleitner S., Applications of a simultaneous assay of ascorbic acid, dehydroascorbic acid and ascorbic sulphate in biological materials, Analyst. 114 (1989) 83-87.

[9] Doledec S., Chessel D., Rythmes saisonniers et composantes stationnelles en milieu aquatique. I- Description d'un plan 
d'observations complet par projection de variables, Acta Oecol. 8 (1987) 403-426.

[10] Elamin F.M., Wilcox C.J., Milk composition of Marjheim camels, J. Dairy Sci. 75 (1992) 3155-3157.

[11] El-Hatmi H., Khorchani T., Attia H., Characterization and composition of camel's (Camelus dromedarius) colostrum and milk, Microbiol. Hyg. Alim. 18 (2006) 13-17.

[12] Farah Z., Composition and characteristics of camel milk, J. Dairy Res. 60 (1993) 603626.

[13] Farah Z., Rettenmaier R., Atkins D., Vitamin content of camel milk, Int. J. Vitam. Nutr. Res. 62 (1994) 30-33.

[14] Farah Z., Rüegg M., The creaming properties and size distribution of fat globules in camel milk, J. Dairy Sci. 74 (1991) 2901-2904.

[15] Faye B., Productivity potential of camels, in: Faye B., Esenov P. (Eds.), Proceedings of International Workshop, Desertification combat and food safety, the added value of camel producers, Ashkhabad, Turkmenistan, April 19-22, 2004, Vol. 362 NATO Sciences Series, Life and Behavioural Sciences, IOS Press Publisher, Amsterdam, The Netherlands, 2005, pp. 127-134.

[16] Indra R., Erdenebaatar B., Camel's milk processing and its consumption patterns in Mongolia, in: Bonnet P. (Ed.), Actes de l'atelier Chameaux et dromadaires, animaux laitiers, Nouakchott, Mauritania, Oct. 24-26, 1994, CIRAD, Montpellier, France, 1998, pp. 257-261.

[17] Indra P., Magatch A., Batsoour L., Mongol Bactrian camel [Mongol Temet], Mongolia State University of Agriculture Publishing, Oulaan-Bator, Mongolia, 2003.

[18] Jianlin H., Mburu D., Ochieng J., Kaufmann B., Rege J., Hanotte O., Application of new world Camelidae microsatellite primers for amplification of polymorphic loci in Old World Camelids, Anim. Genet. 31 (2000) 404-406.

[19] Konuspayeva G., Variabilité physicochimique et biochimique du lait des grands camélidés (Camelus bactrianus, Camelus dromedarius et hybrides) au Kazakhstan, Ph.D. in Food sciences, Université Montpellier II, France, 2007.

[20] Konuspayeva G., Faye B., A better knowledge of milk parameters, a preliminary step for improving the camel milk market opportunity in a transition economy. The case of Kazakhstan, in: Kohler-Rolleifson I., Rathore S. (Eds.), Proceedings of International Conference on Saving the camel and peoples' livelihood, Sadri, Rajasthan, India, Nov. 23-25, 2004, LPPS Publisher, Sadri, India, 2004, pp. 28-36.

[21] Konuspayeva G., Faye B., Loiseau G., Levieux D., Lactoferrin and immunoglobin content in camel milk from Kazakhstan, J. Dairy Sci. 90 (2007) 38-46.

[22] Konuspayeva G., Loiseau G., Faye B., La plus-value "santé" du lait de chamelle cru et fermenté, l'expérience du Kazakhstan, in: Actes des 11èmes Rencontres autour des Recherches sur les Ruminants, INRA, Institut de l'Élevage, Paris, France, 2004, pp. 47-50.

[23] Mohamed H.E., Mousa H.M., Beynen A.C., Ascorbic acid concentrations in milk from Sudanese camels, J. Anim. Physiol. Anim. Nut. 89 (2005) 35-37.

[24] Narmuratova M., Konuspayeva G., Loiseau G. Serikbaeva A., Barouh N., Montet D., Faye B., Fatty acids composition of dromedary and Bactrian camel milk in Kazakhstan, J. Camel Pract. Res. 13 (2006) 45-50.

[25] Ramet J.P., La transformation en fromages de lait de dromadaire, Rev. Mond. Zootech. 67 (1991) 20-28.

[26] Ripley B.D., Pattern recognition and neural networks, Cambridge University Press, Cambridge, UK, 1996.

[27] Sawaya W.N., Khalil J.K., Al-Shalhat M., Al-Mohammed H., Chemical composition and nutritional quality of camel milk, J. Food Sci. 49 (1984) 744-747.

[28] Tasov A., Alybaev N., Camel genetic resources and ways of camel breeding products use for population of Kazakhstan arid areas, in: Faye B., Esenov P. (Eds.), Proceedings of International Workshop, Desertification combat and food safety, the added value of camel producers, Ashkhabad, Turkmenistan, April 19-22, 2004, Vol. 362 NATO Sciences Series, Life and Behavioural Sciences, IOS Press Publisher, Amsterdam, The Netherlands, 2005, pp. 121-123.

[29] Terenytev C.M., Camel farming [Verbludov skotovodstvo], Kolos Publisher, Moscow, Russia, 1975.

[30] Venables V.N., Ripley B.D., Modern applied statistics with S, 4th Edn., Springer Publisher, New York, USA, 2003.

[31] Zhao X.X., Milk production of Chinese Bactrian camel (Camelus bactrianus), in: Bonnet P. (Ed.), Actes de l'atelier Chameaux et dromadaires, animaux laitiers, Nouakchott, Mauritania, Oct. 24-26 1994, CIRAD, Montpellier, France, 1998, pp. 101105 . 